24. SOUSA, P.J. and W.N. MCDONAL. 1983. Habitat suitability models: Baird's Sparrow. U.S. Dept. Int., Fish Wildl. Serv. FWS/OBS-82/10.44. 12 pp.

25. STEWART, R.E. 1975. Breeding birds of North Dakota. Tri-college Center for Environmental Studies, Fargo, ND. $295 \mathrm{pp}$.

26. STEWART, R.E. and H.A. KANTRUD. 1972. Population estimates of breeding birds in North Dakota. Auk 89:766-788.

27. SUTTER, G.C., T. TROUPE and $M$. FORBES. 1995. Abundance of Baird's Sparrows, Ammodramus bairdii, in native prairie and introduced vegetation. Ecoscience 2:344-348.

28. THOMPSON, E.E. 1891. The birds of Manitoba. Proceedings of the United States National Museum. 13:457-643. Second edition reprinted (1975) by Premium Ventures, Winnipeg, MB.

29. WERSHLER, C. 1990. Status of the Baird's Sparrow in Alberta. Unpublished draft prepared for World Wildlife Fund Canada, Endangered Species Recovery Fund and Alberta Fish and Wildlife.

30. JOHNSON and IGLE pers. comm.

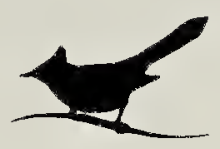

POETRY

\title{
A NURSERY RHYME
}

Sing a song of sixpence

A pocket full of rye

Four and twenty blackbirds baked in a pie,

When the pie was opened the birds began to sing

Wasn't that a dainty dish to set before the king?

Editor's note: This nursery rhyme from the Middle Ages is based on fact. It was popular amusement at major feasts to bake a pie shell and then seal a group of songbirds inside. In this case they used the abundant Eurasian Blackbird, a black-coloured equivalent of our Robin. When the pie was cut in front of the unsuspecting guests the birds would burst forth, to the startled amusement of all. The practice was short-lived, as the novelty soon wore off. 